\title{
TATANAN KEHIDUPAN BARU PADA AKOMODASI DAN RESTORAN PARIWISATA
}

\author{
Ni Made Rai Kristina ${ }^{1}$, I Gusti Ketut Indra Pranata Darma ${ }^{2}$ \\ ${ }^{l}$ Universitas Hindu Negeri I Gusti Bagus Sugriwa Denpasar
}

\begin{abstract}
ABSTRAK
Industri perhotelan merupakan salah satu bagian dari dunia Pariwisata yang memegan peranan penting dimanapun berada. Peran industri perhotelan ini tidak hanya sebagai tempat untuk singgah dan beristirahat, melainkan menjadi sebuah awal dari kegiatan perekonomian dari industri lain. Datangnya virus covid-19 di awal tahun 2020, tak pelak memukul segala sektor industri yang ada didunia tidak terkecuali industri perhotelan. Selama hampir 3 bulan, masyarakat di dunia dipaksa untuk hidup berada dalam ketakutan akan virus covid-9. World Health Organization (WHO) pun menyerukan adanya tatanan kehidupan baru sebagai bentuk adaptasi baru bagi seluruh masyarakat di dunia terhadap virus ini sampai ditemukan obatnya.

Berdasarkan adanya virus tersebut, industri pariwisata yang memiliki berbagai macam akomodasi ikut menyambut tatanan kehidupan baru dengan mengikuti aturan-aturan ketat yang berlaku mengikuti anjuran pemerintah setempat. Pada penelitian ini akan mencoba mengetahui bentuk protokol tatanan kehidupan baru pada beberapa akomodasi dan restoran di Bali yang merupakan salah satu daerah yang terdampak secara signifikan. Metode yang dilakukan dengan melakukan kajian langsung kelapangan dan studi literatur. Sehingga diharapkan dapat menemukan langkah-langkah yang tepat untuk diterapkan bagi daerah lain dengan mengikuti kebiasaan yang berlaku di daerah tersebut.
\end{abstract}

Kata Kunci: Perhotelan, Covid, Tatanan Kehidupan Baru

\section{ABSTRACT}

The hospitality industri is one part of the world of tourism which plays an important role wherever located. The role of the hospitality industri is not only as a place to stop and rest, but it is a beginning of the economic activities of other industries. The arrival of covid-19 virus in early 2020, no doubt hit all the industrial sectors in the world including the hospitality industri. For almost 3 months, people in the world are forced to live in fear of the covid-9 virus. The World Health Organization (WHO) also called for new life order as a new form of adaptation for all people in the world to this virus until a cure is found.

Based on the presence of the virus, the hotel industri has welcomed new life by following strict rules in force following local government recommendations. This research will try to find out the form of the new life protocol accommodation at bali which get significant impact. The method using direct study and literature. So hopefullye get the right steps to be applied to other regions by following the prevailing customs in the area.

Keywords : Hospitality, Covid, New Life 
Copyright @2021. UHN IGB Sugriwa Denpasar. All Right Reserved

Bali yang sudah beberapa kali mendapat beberapa kejadian yang cukup memukul.

Berdasarkan permasalahan mengenai

\section{PENDAHULUAN}

Pariwisata sebagai salah satu industri yang bergerak cukup dinamis pada masa kini serta memiliki tingkat kerentanan terhadap isu. Konsep pada pariwisata merupakan konsep yang cukup multidimensional yang artinya memiliki banyak sudut pandang kajian (Pitana, I Gde; Surya Diarta, 2009). Beberapa unsur pokok yang terkandung di dalam pariwisata antara lain: adanya unsur perjalanan, adanya menempati tempat baru sementara, dan tujuan utama tidak mencari nafkah(Gayatri, 2005).

Bali merupakan salah satu pulau yang cukup menggantungkan pergerakan ekonomi pada industri pariwisata. Hingga virus covid19 yang menyerang dunia, ikut melumpuhkan hampir semua sektor industri tidak terkecuali pariwisata. Virus SARSC$\mathrm{CoV}-12$ yang lebih dikenal dengan virus covid-19 awal terdeteksi di Cina dengan belum diketahui penyebab asal mula terjadinya saat ini (Advisory, 2020). Virus covid menyerang saluran pernafasan manusia, yang pasti mengganggu kehidupan manusia dalam beraktivitas terutamanya pariwisata. Perkembangan yang cepat dari virus ini, membuat banyak kota dan Negara yang mulai memberlakukan kebijakan lockdown di tempatnya (Saadat, Rawtani, \& Hussain, 2020). Penutupan kota dan Negara tersebut tentu menjadi suatu permasalahan tersendiri bagi industri pariwisata.

Organisasi pariwisata dunia memperkirakan terjadi penurunan 20 sampai 30 persen kunjungan wisatawan di seluruh dunia terdampak covid-19 (UNWTO, 2020). Penurunan tersebut tentu menjadi suatu perhatian khusus bagi sector industri yang terdampak adanya covid-19. Meski demikian, masih terdapat optimism dari para pelaku industri pariwisata khususnya pada bidang perhotelan bahwa pandemi ini hanya akan berlaku selama 4-6 bulan saja (Horwath, 2020). Analisa tersebut menjadi sebuah angin segar bagi industri pariwisata terutama di akomodasi dan restoran selama pandemi serta konsistensi penerapan tatanan kehidupan baru, penulis tertarik untuk mengangkat mengenai Tatanan Kehidupan baru pada akmodasi pariwisata. Pada beberapa akomodasi yang masih berjalan selama masa pandemi, akan dicari langkah yang dapat dilaksanakan selama kondisi ini terjadi.

\section{LITERATUR REVIEW}

\section{Tatanan Kehidupan baru pasca Covid-19}

Istilah tatanan kehidupan baru merupakan suatu istilah yang digengungkan oleh badan kesehatan dunia (WHO) dalam menyikapi adanya pandemi covid-19 yang diprediksi akan berjalan cukup lama. Hingga tulisan ini terbit, Covid-19 sudah 1 tahun lebih bersama kehidupan manusia. Virus covid-19 sendiri merupakan jenis virus baru yang menyerang saluran pernafasan manusia (Yuliana, 2020). Virus ini memiliki kemiripan dengan adanya virus SARS dan MERS yang sebelumnya pernah menyerang manusia (Advisory, 2020). Covid-19 ini tentu akan sangat menggangu kehidupan masyarakat dalam beraktivitas maupun dalam kegiatan pariwisata, sehingga diperlukan sebuah tatanan kehidupan baru yang disebut tatanan kehidupan baru.

Penyebutan kehidupan normal baru (New Normal) merupakan suatu kegiatan adaptasi manusia saat ini terhadap kondisi tertentu (dalam hal ini dengan virus covid19). Meski demikian tidak menutup kemungkinan bahwa akan terjadi suatu peningkatan kasus baru covid-19 secara signifikan jika tidak menerapkan protokol kesehatan secara tepat (World Health Organization, 2020).

Tatanan kehidupan baru bermula dari adanya virus Covid-19 yang menyebabkan kontak fisik antar manusia menjadi 
berkurang hingga pembatasan berskala besar dalam bepergian. Adanya pembatasan tersebut telah merubah stabilitas, normalitas serta meningkatkan stress di masyarakat (Bard, 2020) $\square$.

Kemungkinan untuk kembali pada kehidupan normal yang telah dijalani sebelumnya akan cukup lama terlaksana saat ini. Menjadi tantangan baru dalam kehidupan tatanan baru dalam mengadaptasi segala sektor industri yang ada saat ini(Taylor dalam Ateljevic, 2020) $\square$. Tantangan tersebut menjadi alasan diterapkannya tatanan kehidupan baru. Kebutuhan manusia akan perekonomian yang baik mendesak pula masyarakat untuk tetap bekerja hingga tatanan kehidupan baru tersebut diberlakukan. Pada dunia kesehatan pun, kehidupan normal lama yang diharapkan akan memerlukan waktu yang tidak sebentar (Zeegen, Yates, \& Jevsevar, 2020) $\square$. Kehidupan normal lama yang kita jumpai masih memerlukan waktu yang tidak sebentar dan tatanan hidup baru diperlukan sebuah latihan serta kebiasaan untuk mencapainya saat ini. Proses adaptasi tersebut tetap dipercaya merupakan suatu langkah terbaik yang dapat kita jalankan saat ini.

Pada kehidupan tatanan baru, juga membuka peluang baru bagi masyarakat. Tatanan kehidupan baru menjadi inspirasi masyarakat dalam melakukan inovasi kegiatan. Pada dunia kerja saat ini menjadi lebih fleksibel dalam bekerja meskipun terpisah jarak yang jauh. Seperti dalam pengurusan surat menyurat maupun berkas yang sebelumnyaa memerlukan fisik menjadi dalam bentuk digital, sekarang menjadi lebih fleksibel penerapannya (Clark, 2020) $\square$.

Keleluasaan dalam berkegiatan juga akan mulai berdampak pada industri perhotelan. Pelayanan secara "flexyservices" akan menjadi suatu alat baru dalam menarik perhatian wisatawan dalam melakukan kunjungan (Ranasinghe et al., 2020). Inovasi dalam menggabungkan kegiatan secara luring dan daring menjadi hal yang lumrah saat ini. Penyelenggaraa kegiatan MICE juga akan mulai berjalan secara virtual selama penurunan wisatawan hingga virus covid-19 dapat teratasi.

Penurunan wisatawan ini cukup berdampak bagi banyak industri yang bergantung pada pariwisata. Diperlukan campur tangan dari pemerintah setempat dalam menjaga industri pariwisata dengan memberikan relaksasi pajak maupun insentif tertentu dalam menjaga keberlangsungan kehidupan suatu usaha (Kumar, 2020). Kehidupan industri pariwisata dalam tatanan kehidupan baru akan membutuhkan banyak investasi dalam menjalankan tatanan kehidupan baru tersebut. Mulai penyediaan alat kebersihan lebih, proses pembersihan ruangan hingga sterilisasi terhadap kasuskasus wisatawan yang mungkin saja terjangkit virus covid-19.

Penerapan protokol kesehatan menjadi metode yang dapat dilaksanakan saat ini sampai adanya solusi nyata bagi industri pariwisata yang efektif (Krisdayanthi, 2020). Terlihat penerapan protokol kesehatan dapat sedikit membantu meningkatkan kunjungan wisatawan pada beberapa daya Tarik wisata.

\section{Akomodasi dan Restoran}

Akomodasi merupakan sebuah tempat yang digunakan seseorang untuk tinggal sementara dalam waktu kurang dari 12 jam (Putri, 2018). Definisi tersebut mengidentikkan akomodasi degan tempat menginap seperti hotel, homestay maupun guest house. Definisi lain menyebutkan bahwa akomodasi merupakan usaha yang menyediakan pelayanan penginapan yang dapat dilengkapi dengan pelayanan pariwisata lainnya(Menteri Pariwisata dan Ekonomi Kreatif Republik Indonesia, 2019).

Akomodasi membuat kehidupan secara sementara bagi wisatawan dengan berbagai macam fasilitas pendukungnya (Cook, Hsu, \& Taylor, 2018). Fasilitas pendukung seperti ruang pertemuan, penyewaan kendaraan menjadi salah satu daya tarik bagi sebuah akomodasi. Akomodasi menjadi salah satu sector terbesar disamping sektor ekonomi 
yang yang memiliki fasilitas pendukung penting. Salah satu fasilitas pendukung yang hampir lekat dengan akomodasi adalah restoran.

Restoran merupakan tempat atau bangunan yang diorganisasi secara komersil(Marsum, 2005). Restoran juga memberikan pelayanan kepada wisatawan berupa makanan dan minuman. Secara umum restoran menjadi salah satu sektor yang menopang pemasukan dari akomodasi.

\section{METODE}

Dalam menyusun penelitian ini, penulis melakukan wawancara serta pengamatan langsung ke pengelola industri perhotelan maupun restoran sebagai salah satu bagian dari akomodasi dan restoran pada pariwisata sehingga didapatkan hasil wawancara yang akurat bahkan didapatkan hasil baru dari kegiatan yang dilakukan.

Dalam penelitian kali ini, teknik sampling yang digunakan adalah purposive sampling. Pada teknik cuplikan ini, peneliti melakukan beberapa wawancara formal dan informal secara mendalam kepada informan dalam mengetahui kondisi terkini. Waktu penelitian dilakukan pada bulan Oktober 2020 hingga Maret 2021 dengan mengambil beberapa lokasi di ubud dan Denpasar.

\section{HASIL DAN PEMBAHASAN}

\section{New Normal dalam Industri Perhotelan}

Industri Perhotelan yang mengedepankan pelayanan serta keramahan dalam melayani wisatawan, tidak bisa terlepas dari kontak langsung kepada segala macam barang wisatawan. Munculnya virus covid-19 menjadi sebuah dilema tersendiri bagi industri perhotelan ini. Pemerintah Indonesia turut memberikan langkah nyata dengan mencetuskan tatanan kehidupan normal baru atau yang disebut tatanan kehidupan baru.

Industri perhotelan mengadaptasi tatanan kehidupan baru ini dengan lebih fleksibel. Fleksibilitas dapat diterapkan dengan mengurangi kontak langsung dalam kegiatan fisik seperti surat menyurat (Clark, 2020).
Fleksibilitas menjadi suatu kunci dalam tetap mengurangi penyebaran covid-19.

Beberapa tatanan kehidupan baru yang dapat diterapkan pada industri perhotelan antara lain (PHRI, 2020):

1. Memeriksa suhu tubuh karyawan yang diatas 37,3 derajat Celcius.

2. Penerapan gaya hidup bersih karyawan dengan rajin mencuci tangan sebelum, selama dan sesudah bekerja.

3. Penggunaan masker saat akan menuju lokasi hotel, dan mengganti masker saat akan memulai bekerja di hotel.

4. Penyediaan hand sanitizer pada lokasi yang dianggap perlu oleh pihak hotel.

5. Menghindari kerumunan

6. Mengurangi kontak fisik dalam melakukan registrasi tamu

Penerapan protokol baru tersebut di dalam hotel, diperlukan suatu kebiasaan dalam jangka waktu tertentu.

Pada Villa di Ubud, penerapan protokol kesehatan dilakukan pada awal masuk dan dilakukan pemeriksaan suhu. Dikarenakan hunian kamar tidak terlalu tinggi, sehingga penerapan jaga jarak terlaksana tanpa perlu adanya arahan dari pengelola.

Pada salah satu akomodasi restoran di tegallalang, penerapan protokol kesehatan sudah dimulai saat memasuki jalan setapak menuju akomodasi dengan penyiapan tempat cuci tangan. Kemudian di lokasi setiap tamu dicek suhu serta cuci tangan kembali. Pada lokasi akomodasi, jarak antar tamu terpantau sejauh 1 meter sehingga penerapan jaga jarak cukup terpenuhi.

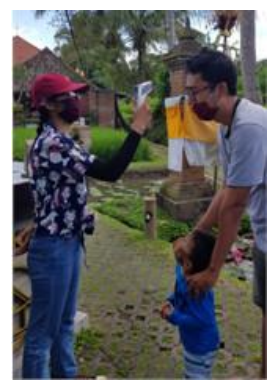

Gambar 1. Pemeriksaan suhu pada pintu masuk restoran

Penerapan protokol kesehatan pada restoran dilakukan pada salah satu gerai makanan cepat saji terkemuka di bali yang secara 
konsisten melakukan pemeriksaan suhu di awal masuk pintu restoran. Pengetatan dalam menjaga jarak antar tamu juga mengalami perubahan signifikan sebelum dan sesudah masa pandemi.

Pada restoran cepat saji, penggunaan teknologi semakin ditingkatkan demi tetap menjaga tingkat penjualan meski tidak bisa seramai sebelum masa pandemi. Langkah tersebut menjadi suatu tindakan preventif bagi perusahaan untuk meminimalisir pengurangan tenaga kerja pula.
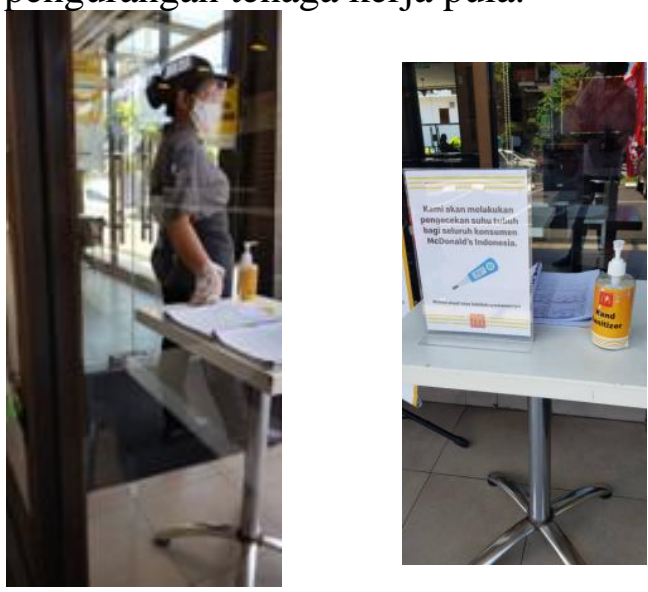

Gambar 2. Penerapan protokol kesehatan pada salah satu gerai makanan modern

Pada salah satu restoran terkemuka di gianyar, masih dijumpai belum konsistennya penerapan protokol kesehatan yang terlihat dari tidak adanya pemeriksaan suhu sebelum memasuki kawasan restoran meskipun disediakan tempat mencuci tangan.

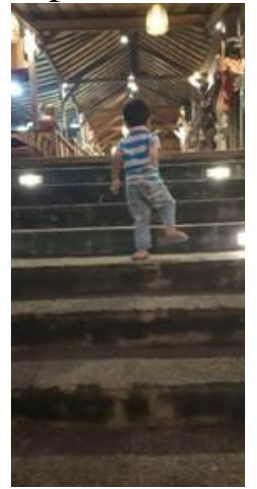

Gambar 3. Pintu masuk restoran

Pada kunjungan awal di 3 akomodasi yang telah dilakukan, ada beberapa hal yang menjadi sorotan diantaranya:

1. Keseragaman antar akomodasi yang belum merata.
2. Masih terbatasnya himbauanhimbauan secara tertulis di beberapa akomodasi dalam mengingatkan tamu mengenai kepatuhan akan protokol kesehatan..

Penerapan protokol menjadi hal mutlak selama masa pandemi yang saat ini terjadi. Langkah penerapan protokol menjadi solusi nyata bagi akomodasi untuk kembali memulihkan dari adanya ancaman pandemi covid (Krisdayanthi, 2020). Menjadi penting dalam konsistensi pelaksanaan protokol kesehatan, menghindari adanya perbedaan dalam satu tempat dengan tempat lain demi menjaga akomodasi dan restoran tetap berjalan meski dalam masa pandemi.

\section{III.SIMPULAN}

Pandemi menjadi sebuah musuh bagi sebagian besar akomodasi dan restoran. Isu kesehatan, keamanan menjadi sebuah isu yang mampu menyerang industri pariwisata. Penerapan protokol kesehatan secara ketat dan konsisten mejadi salah satu kebiasaan baru bagi akomodasi dan restoran selama masa pandemi. Perubahan kebiasaan menjadi perubahan kebiasaan baru pula baik bagi wisatawan maupun bagi pengelola. Kondisi tersebut juga mampu memunculkan kreativitas bagi pengelola dalam mengoptimalkan teknologi hingga masa pandemi dapat berubah menjadi endemi.

\section{REFERENSI}

Advisory, F. I. P. H. (2020). CORONAVIRUS SARS-CoV-2 / COVID-19 PANDEMI : Information and interim guidelines for pharmacists and the pharmacy workforce Coronavirus SARS-CoV-2 / COVID-19 pandemi : (March), 0-48.

Ateljevic, I. (2020). Transforming the (tourism) world for good and (re)generating the potential 'new normal.' Tourism Geographies. https://doi.org/10.1080/14616688.2020. 1759134 
Bard, T. R. (2020). COVID-19 and a New Normal? The Journal of Pastoral Care \& Counseling : JPCC. https://doi.org/10.1177/1542305020926 831

Clark, K. (2020). Innovation in a post-Covid "new normal." The Veterinary Record. https://doi.org/10.1136/vr.m1938

Cook, R. A., Hsu, C. H. C., \& Taylor, L. L. (2018). Tourism : The Business of Hospitality and Travel (Sixth Edit). Pearson.

Krisdayanthi, A. (2020). New Normal Pariwisata Bali di masa Pandemi pada Daerah Tujuan Wisata Tanah Lot, Kabupaten Tabanan. 2(1).

Kumar, V. (2020). Indian Tourism Industri and COVID-19: Present Scenario. Journal of Tourism and Hospitality Education. https://doi.org/10.3126/jthe.v10i0.28768

Marsum. (2005). Restoran dan Segala Permasalahannya. ANDI Yogyakarta.

Menteri Pariwisata dan Ekonomi Kreatif Republik Indonesia. (2019). Peraturan Menteri Pariwisata dan Ekonomi Kreatif Republik Indonesia Nomor PM.53/HM.001/MPEK/2013 tentang Standar Usaha Hotel. Journal of Chemical Information and Modeling, 53(9), 1689-1699. Retrieved from https://peraturan.bkpm.go.id/jdih/userfil es/batang/PERMEN ttg Standar Usaha Hotel.pdf

PHRI, B. P. P. (2020). PANDUAN UMUM NORMAL BARU HOTEL DAN RESTORAN.

Putri, E. D. H. (2018). Pengantar Akomodasi dan Restoran. Deepublish.

Ranasinghe, R., Damunupola, A., Wijesundara, S., Karunarathna, C., Nawarathna, D., Gamage, S., ... Idroos, A. A. (2020). Tourism after Corona: Impacts of Covid 19 Pandemi and Way Forward for Tourism, Hotel and Mice
Industri in Sri Lanka. SSRN Electronic Journal. https://doi.org/10.2139/ssrn.3587170

World Health Organization. (2020). Coronavirus Disease Situation Report World Health World Health Organization Organization (Vol. 19). Retrieved from https://covid19.who.int/

Yuliana. (2020). Wellness and healthy magazine. 2(February), 187-192.

Zeegen, E. N., Yates, A. J., \& Jevsevar, D. S. (2020). After the COVID-19 Pandemi: Returning to Normalcy or Returning to a New Normal? Journal of Arthroplasty. https://doi.org/10.1016/j.arth.2020.04.04 0 